\title{
Genetic Vaccination-Induced Immune Responses to the Human Immunodeficiency Virus Protein Rev: Emergence of the Interleukin 2-Producing Helper T Lymphocyte
}

\author{
SHERRI Y. CHAN, ${ }^{1}$ MARISA C. LOUIE, ${ }^{1}$ JOSEPH R. PICCOTTI, ${ }^{1}$ GAITRY IYER, ${ }^{1}$ XU LING, ${ }^{2}$ \\ ZHI-YONG YANG, ${ }^{2}$ GARY J. NABEL, ${ }^{2-4}$ and D. KEITH BISHOP ${ }^{1,5}$
}

\begin{abstract}
Rev M10 is a trans-dominant negative inhibitor of HIV replication. Hence, stable transduction of $\mathrm{CD}^{+}{ }^{+} \mathrm{T}$ cells with Rev M10 represents a novel gene therapy aimed at inhibiting HIV replication within these cells, thereby slowing the progression of AIDS. However, the immune system may recognize Rev M10 as foreign and target transduced cells for elimination. In the current study, mice were genetically immunized with a plasmid encoding Rev M10, to (1) identify immune parameters that may be induced by Rev M10 gene transfer, (2) determine the impact of repeated introduction of the Rev M10-encoding plasmid on the immune response to the transgene product, and (3) determine if cotransfection with a plasmid encoding TGF $\beta 1$ would suppress the response. Kinetic studies revealed that Rev-specific IL-2-producing helper T lymphocytes (HTLs) appeared following the second genetic immunization, peaked after the third, and persisted at peak levels for at least 6 weeks. Rev-specific HTLs were $\mathrm{CD}^{+}$, and the development of these cells was ablated by cotransfection with TGF $\beta 1$. Other cytokines were not readily detectable when immune splenocytes were restimulated with Rev in vitro, and Rev-specific IgG antibodies were not present in the sera of these mice. To our knowledge, this represents the first report that genetic immunization with Rev M10 induces an immune response that is dominated by IL-2-producing HTLs. Further, this study demonstrates the potential utility of introducing immunosuppressive genes as a means to control the immune response to foreign transgene products.
\end{abstract}

\section{OVERVIEW SUMMARY}

The immune system poses a major obstacle to the long-term success of in vivo gene therapies. Immune responses to foreign transgene products and/or the vectors that facilitate gene transfer may neutralize the transgene product, eliminate transfected cells, and culminate in inflammation within transfected tissues. The majority of studies that address these issues have focused on cytotoxic T lymphocyte (CTL) and antibody responses induced by gene transfer. However, the IL-2-producing helper T lymphocyte (HTL) represents a critical regulatory cell that likely influences the inductive phase of the immune response following gene transfer. The current study employed limiting dilution analysis (LDA) techniques to characterize the development of IL-2-producing HTLs induced by genetic vaccination with a plasmid encoding the mutated HIV protein Rev M10. Further, we assessed the ability to inhibit the transgene-induced HTL response by cotransfer of a plasmid encoding the immunosuppressive cytokine TGF $\beta 1$.

\section{INTRODUCTION}

He TRANSFER OF ANTIVIRAL GENES represents a novel strat-
egy aimed at inhibiting human immunodeficiency virus
(HIV) replication and the subsequent decay of the immune sys-
tem in HIV-infected individuals. The nuclear protein Rev serves
as a likely target for this gene transfer-based modality, in that
Rev is essential for viral replication. Rev acts in concert with
host cell factors to facilitate the export of unspliced viral
mRNAs into the cytoplasm, and is thought to be important in

${ }^{1}$ Department of Surgery, ${ }^{2}$ Department of Internal Medicine, ${ }^{3}$ Department of Biological Chemistry, Howard Hughes Medical Institute ${ }^{4}$ and ${ }^{5}$ Department of Microbiology and Immunology, University of Michigan Medical Center, Ann Arbor, MI 48109. 
regulating virus latency (Cullen et al., 1988; Malim et al., 1991; Liu et al., 1994). Introduction of two point mutations in a highly conserved region of Rev gives rise to a defective protein, Rev M10, which acts as a trans-dominant negative inhibitor of wildtype Rev (Sodroski et al., 1986; Malim et al., 1989, 1992; Bevec et al., 1992; Bahner et al., 1993). Importantly, transfection of human T cells with Rev M10 inhibits viral replication following challenge with HIV in vitro (Malim et al., 1992; Bevec et al., 1992; Woffendin et al., 1994).

The immune system has an exquisite ability to discriminate self from non-self and mount a variety of effector mechanisms aimed at eliminating non-self. Since many gene transfer protocols introduce foreign transgenes, this aspect of the immune system may or may not be beneficial, depending on the intended outcome of the therapy. For example, Tang et al. (1992) were the first to demonstrate the utility of gene transfer for deliberate immunization to a transgene product. This approach has since proved useful in generating immune responses to infectious disease agents and tumors (Robinson et al., 1993; Yankauckas et al., 1993; Raz et al., 1994; Davis et al., 1995; Michel et al., 1995; Mor et al., 1995; Huygen et al., 1996; Schirmbeck et al., 1996). However, the success of gene transfer strategies designed as replacement therapies to correct genetic disorders may be compromised by the immune response to the transgene product. Indeed, numerous reports have verified that the immune system represents a major obstacle to the success of in vivo gene replacement therapies (Kay et al., 1994; Blaese et al., 1995; Dwarki et al., 1995; Fang et al., 1995; Kozarsky et al., 1996; Riddell et al., 1996; Tripathy et al., 1996; Hurwitz et al., 1997). Both conventional and experimental immunosuppressive protocols have been employed in an attempt to control gene transfer-induced immune responses (Fang et al., 1995; Kay et al., 1995; DeMatteo et al., 1996; Yang et al., 1996).

Similarly, the success of Rev M10-based gene therapies aimed at protecting $\mathrm{T}$ cells from HIV replication is dependent on the in vivo persistence of Rev M10-transduced cells. However, Rev M10 represents a foreign protein that may be targeted by the immune system, possibly leading to the elimination of transduced cells. While sequential administrations of Rev M10transduced cells may temporarily replace those cells eliminated by the immune system, repeated introduction of the foreign transgene would likely amplify the anti-Rev M10 immune response. The current study was designed to elucidate parameters of the immune response that may be induced by Rev M10 gene transfer, and to assess quantitatively the effects of repeated gene transfer on the anti-Rev immune response. We have previously reported that the emergence of antigen-specific interleukin 2 (IL-2)-producing helper T lymphocytes (HTLs) reflects in vivo immune responses that culminate in inflammation and tissue damage (Bishop et al., 1992; DeBruyne et al., 1993, 1995). Hence, we employed limiting dilution analysis (LDA) techniques to quantify Rev-specific HTLs, and assessed the development of Rev-specific antibodies following multiple intramuscular injections with a plasmid encoding Rev M10. In addition, cotransfer of a plasmid encoding transforming growth factor $\beta 1$ (TGF $\beta 1$ ) was employed as an immunosuppressive modality aimed at ablating the anti-Rev HTL response. The data reveal that HTLs, but not antibodies, are induced by genetic vaccination with Rev M10. Further, these data suggest that coadministration of an immunosuppressive gene may enhance the efficacy of in vivo gene transfer by inhibiting the HTL response to the transgene product.

\section{MATERIALS AND METHODS}

\section{Mice}

Female BALB/c and C57BL/6 mice between 6 and 12 weeks of age were obtained from Charles River Laboratories (Raleigh, $\mathrm{NC}$.

\section{Medium}

The culture medium used in these studies was Dulbecco's modified Eagle's medium (DMEM) supplemented with $1.6 \mathrm{mM}$ L-glutamine, $0.27 \mathrm{~m} M$ L-asparagine, $1.4 \mathrm{~m} M$ L-arginine- $\mathrm{HCl}$, $14 \mathrm{~m} M$ folic acid, $10 \mathrm{~m} M$ HEPES buffer, $1.0 \mathrm{~m} M$ sodium pyruvate, penicillin/streptomycin (100 units/ml), 2\% heat-inactivated fetal calf serum (FCS) (all obtained from Life Technologies, Grand Island, NY), and $5 \times 10^{-5} M 2$-mercaptoethanol (2-ME; Sigma Chemicals, St. Louis, MO).

\section{Rev M10 genetic vaccination}

The Rev M10 expression plasmid pCMV Rev M10 was constructed by inserting the Rev M10 cDNA into the $X b a I$ and Pst I sites of pVR1332 T $\beta$. This backbone contains the cytomegalovirus (CMV) enhancer, promoter, and first intron to increase expression, the rabbit $\beta$-globin polyadenylation sequence, and the kanamycin resistance gene. $\mathrm{BALB} / \mathrm{c}$ or C57BL/6 mice were genetically vaccinated by multiple intramuscular injections with pCMV Rev M10. Plasmid injections (100 $\mu \mathrm{g}$ of DNA total, $50 \mu \mathrm{g} / \mathrm{hind}$ limb) were administered 2 weeks apart, and splenocytes were harvested 10 days following the last plasmid injection. Where indicated, pCMV Rev M10 was admixed with an equal concentration of VR1012 $\mathrm{TGF} \beta$, which encodes the active form of human TGF $\beta 1$. The VR1012 backbone contains the CMV enhancer, promoter, and first intron to increase expression, the bovine growth hormone polyadenylation sequence, and the kanamycin resistance gene. Where indicated, mice were immunized with the control plasmid VR1012 $\beta$-gal, which encodes $\beta$-galactosidase.

\section{Proliferative responses to Rev}

Splenocytes $\left(2 \times 10^{5}\right)$ obtained from naive or pCMV Rev M10-immunized mice were added to microtiter plates with varying concentrations of recombinant Rev protein (kindly provided by J. Lee, University of Texas Medical Branch, Galveston, TX). Microcultures were incubated for 7 days including a terminal 16hr pulse with $\left[{ }^{3} \mathrm{H}\right]$ thymidine. Cultures were harvested onto fiber filter mats and $\left[{ }^{3} \mathrm{H}\right]$ thymidine incorporation was determined using a Wallac (Gaithersburg, MD) 1205 Betaplate scintillation counter. Data are represented as the stimulation index, which is calculated as counts per minute (cpm) of responder cells + recombinant Rev protein/cpm of responder cells only.

\section{Limiting dilution analysis for $I L-2$-producing helper T lymphocytes}

A conventional LDA technique (Bishop and Orosz, 1989) was employed to enumerate Rev-reactive IL-2-producing 
HTLs. Appropriate dilutions of cell suspensions were added as responder cells to microtiter wells along with irradiated $(5000$ rad) syngeneic splenocytes as a source of antigen-presenting cells and recombinant Rev protein $(0.1 \mu \mathrm{g} / \mathrm{ml})$. After a $16-\mathrm{hr}$ incubation, $1 \times 10^{3}$ CTLL-20 cells (an IL-2-dependent cell line) were added. Microcultures were incubated an additional $24 \mathrm{hr}$, including a 16-hr terminal pulse with $\left[{ }^{3} \mathrm{H}\right]$ thymidine before harvesting by aspiration. $\left[{ }^{3} \mathrm{H}\right]$ Thymidine incorporation was determined on a Wallac 1205 Betaplate scintillation counter. Individual microcultures were considered positive for IL-2 production if $\left[{ }^{3} \mathrm{H}\right]$ thymidine incorporation exceeded the mean plus $3 \mathrm{SD}$ of $\left[{ }^{3} \mathrm{H}\right]$ thymidine incorporation in microcultures lacking responder cells.

The CTLL-20 cells used in this assay are maintained on recombinant human IL-2 $(200 \mathrm{U} / \mathrm{ml}$; provided by C. Reynolds, NCI, Rockville, MD) and do not respond to IL-4. Further, addition of anti-IL-2 monoclonal antibody (MAb) S4B6.31 eliminates CTLL-20 proliferation in the HTL LDA. Thus, this HTL LDA is specific for IL-2-producing HTLs and does not detect IL-4-producing HTLs.

\section{Limiting dilution analysis for Rev-reactive proliferating $T$ lymphocytes}

The LDA was employed to quantify cells capable of proliferating in response to recombinant Rev in the presence of $\mathrm{IL}$ 2. Dilutions of responder cells were added to microtiter plates with $2 \times 10^{5}$ irradiated syngeneic splenocytes plus $10 \%$ FCS, recombinant human IL-2 $(10 \mathrm{U} / \mathrm{ml})$, and recombinant Rev protein $(0.1 \mu \mathrm{g} / \mathrm{ml})$. Microcultures were incubated for 7 days including a 16-hr terminal pulse with $\left[{ }^{3} \mathrm{H}\right]$ thymidine before harvesting by aspiration onto fiber filter mats. $\left[{ }^{3} \mathrm{H}\right]$ Thymidine incorporation was assessed on a Wallac 1205 Betaplate scintillation counter. Microcultures were considered positive for proliferation if $\left[{ }^{3} \mathrm{H}\right]$ thymidine incorporation exceeded the mean plus $3 \mathrm{SD}$ of $\left[{ }^{3} \mathrm{H}\right]$ thymidine incorporation in microcultures lacking recombinant $\mathrm{Rev}$.

\section{Data analysis}

Minimal estimates of Rev-specific HTLs and proliferating T lymphocytes (PTLs) frequencies were obtained according to the Poisson distribution equation as the slope of a line relating the number of responder cells per microwell (plotted on a linear $x$ axis) and the percentage of microwells that failed to produce IL-2 or proliferate (plotted on a logarithmic $y$ axis). The slope of this regression line was determined by computer, using chisquare minimization analysis as described by Taswell (1981). This analysis yields the minimal frequency estimate, the $95 \%$ confidence interval of the frequency estimate, and a chi-square estimate of probability. Frequency estimates with nonoverlapping $95 \%$ confidence intervals are statistically significant.

\section{ELISA for Rev-reactive antibodies}

Dilutions of sera $(100 \mu \mathrm{l})$ were added in triplicate to plates coated with recombinant Rev protein $(1 \mu \mathrm{g} / \mathrm{ml})$. Anti-Rev $\operatorname{IgG}_{1}$ monoclonal antibody (Advanced Biotechnologies, Columbia, MD) served as a positive control. After a $2-\mathrm{hr}$ incubation at $37^{\circ} \mathrm{C}$, plates were washed three times with phosphate-buffered saline (PBS) containing $1 \%$ bovine serum albumin (BSA). One hundred microliters of biotin-conjugated isotype-specific sec- ondary antibodies $(1 \mu \mathrm{g} / \mathrm{ml})$ was added and plates were incubated at $37^{\circ} \mathrm{C}$ for $1 \mathrm{hr}$. These secondary rat anti-mouse IgM and IgG antibodies were obtained from The Binding Site (San Diego, CA). Plates were washed three times and $100 \mu \mathrm{l}$ of avidin-peroxidase $(1.7 \mu \mathrm{g} / \mathrm{ml}$ ) (Sigma Chemicals) were added. After a 30 -min incubation at room temperature, plates were washed three times and $100 \mu$ of ABTS [2,2'-azino-bis(3-ethylbenzthiazoline-6-sulfonic acid)] substrate (Sigma Chemicals) was added to each well. After $30 \mathrm{~min}$, absorbance was determined at $405 \mathrm{~nm}$ with an EL 312e microplate reader (Bio-Tek Instruments, Winooski, VT).

\section{Cytokine ELISA}

Splenocytes obtained from mice immunized with pCMV Rev M10 were stimulated in vitro at a concentration of $10^{6} / \mathrm{ml}$ with recombinant $\operatorname{Rev}(0.1 \mu \mathrm{g} / \mathrm{ml})$. Supernatants (SNs) were harvested at 24 and $72 \mathrm{hr}$. In some experiments, splenocytes were stimulated with Rev for 5 days, then restimulated with $\operatorname{Rev}$ in fresh medium for an additional $72 \mathrm{hr}$ prior to harvesting SN. SN $(100 \mu 1)$ was added in triplicate to plates coated with rat anti-mouse interferon $\gamma(\mathrm{IFN}-\gamma)$, IL-4, or IL-10 capture antibodies ( $5 \mu \mathrm{g} / \mathrm{ml}$; PharMingen, San Diego, CA). Standards were employed by preparing twofold dilutions of murine recombinant IFN- $\gamma$, IL-4, and IL-10 (PharMingen), with starting concentrations of $25,2.5$, and $10 \mathrm{ng} / \mathrm{ml}$, respectively. After a 1 -hr incubation at room temperature, plates were washed three times with $0.05 \%$ Tween in PBS. One hundred microliters of rat antimouse secondary biotinylated antibodies $(1 \mu \mathrm{g} / \mathrm{ml}$; PharMingen) were then added, and plates were incubated at room temperature for $45 \mathrm{~min}$. Plates were then washed three times with $0.05 \%$ Tween in PBS, and $100 \mu$ l of avidin-peroxidase (Sigma Chemicals) were added. After a 30-min incubation at room temperature, plates were washed three times with $0.05 \%$ Tween in PBS, and $100 \mu \mathrm{l}$ of ABTS substrate (Sigma Chemicals) were then added to each well. After $30 \mathrm{~min}$, absorbance was determined at $405 \mathrm{~nm}$ with an EL $312 \mathrm{e}$ microplate reader (Bio-Tek Instruments). Sample cytokine concentrations were calculated from a standard curve. The sensitivity of this assay is approximately $300 \mathrm{pg} / \mathrm{ml}$ for IFN- $\gamma, 100 \mathrm{pg} / \mathrm{ml}$ for IL-4, and $150 \mathrm{pg} / \mathrm{ml}$ for IL-10.

\section{$T$ cell subset depletion}

Splenocytes were depleted of $\mathrm{CD}^{+}$or $\mathrm{CD}^{+} \mathrm{T}$ cells prior to addition to HTL LDA microcultures by complement-mediated cytolysis. Briefly, $1 \times 10^{6}$ splenocytes $/ \mathrm{ml}$ were incubated for $1 \mathrm{hr}$ on ice with a 1:100 dilution of either anti-CD4 (GK1.5) or anti-CD8 (2.43) MAb purified from ascites. Splenocytes were then pelleted, resuspended in Low-Tox-M rabbit complement (Accurate Chemicals, Westbury, NY) diluted 1:10, and incubated for $1 \mathrm{hr}$ at $37^{\circ} \mathrm{C}$. Cells were washed three times and resuspended to the appropriate viable cell number for use as responder cells in LDA. Depletion of $\mathrm{T}$ cell subsets was verified by flow cytometry (FACScan; Becton Dickinson, Mountain View, CA) using fluorescein isothiocyanate (FITC)-conjugated anti-CD3, -CD4, and -CD8 MAbs (PharMingen), which revealed that the targeted subset represented $<2 \%$ of the residual splenocyte population. T cell subset depletion versus MAb coating was verified by staining with FITC-conjugated goat anti-rat IgG (Jackson ImmunoResearch Laboratories, Westgrove, PA). 


\section{RESULTS}

\section{Experimental system}

To identify immune parameters induced by genetic vaccination with Rev M10, BALB/c mice were given intramuscular injections with the Rev M10-encoding plasmid pCMV Rev M10. Multiple plasmid injections were administered 2 weeks apart in an attempt to induce a vigorous anti-Rev immune response. Splenocytes were harvested 10 days following the last plasmid injection and assessed for responsiveness to recombinant Rev protein in a variety of immunologic assays. Hence, while mice were genetically immunized with Rev M10, in vitro assays employed Rev as the antigen.

\section{Rev-driven proliferative responses}

As shown in Table 1, splenocytes obtained from mice given three genetic immunizations with pCMV Rev M10, but not from naive animals, proliferated vigorously in response to recombinant Rev protein. A kinetic study revealed that Rev-driven proliferative responses were detectable following the second intramuscular injection with pCMV Rev M10, and peaked following the third (data not shown). Dose-response studies (Table 1) demonstrated that in vitro concentrations of recombinant Rev as low as $0.05 \mu \mathrm{g} / \mathrm{ml}$ were sufficient to drive immune $\mathrm{T}$ cell proliferation (simulation index [SI] of 15.2), but did not induce proliferation of naive cells (SI of 1.8). Given these observations, recombinant Rev was used at $0.1 \mu \mathrm{g} / \mathrm{ml}$ for subsequent in vitro assays.

\section{Rev-reactive helper T lymphocytes responses}

The Rev-driven proliferative responses illustrated in Table 1 were detected without the addition of exogenous $\mathrm{IL}-2$ to the culture system. This suggested that Rev-reactive helper T lymphocytes (HTLs) developed after immunization with pCMV Rev M10, which in turn provided the necessary growth factors for clonal expansion of Rev-reactive $T$ cells. We have previously demonstrated that the presence of IL-2-producing HTLs

Table 1. Proliferative Responses Following Rev M10 GeNETIC IMMUNIZATION ${ }^{a}$

\begin{tabular}{lrrr}
\hline & \multicolumn{3}{c}{ Stimulation index } \\
\cline { 2 - 4 } & \multicolumn{3}{c}{$\operatorname{Rev}(\mu \mathrm{g} / \mathrm{ml})$} \\
\cline { 2 - 4 } & \multicolumn{1}{c}{0.5} & 0.05 \\
\hline Naive splenocytes & 2.5 & 3.9 & 1.8 \\
Rev M10 immune splenocytes & 25.8 & 15.4 & 15.2 \\
\hline
\end{tabular}

${ }^{a} B A L B / c$ mice received three biweekly intramuscular injections of $100 \mu \mathrm{g}$ of plasmid encoding Rev M10. Ten days after the third injection, splenocytes were processed and cultured at $1 \times 10^{6}$ cells $/ \mathrm{ml}$ in $200-\mu l$ volumes for 5 days with varying concentrations of recombinant Rev protein. Cultures received a terminal 18 -hr pulse with $0.5 \mu \mathrm{Ci}$ of $\left[{ }^{3} \mathrm{H}\right]$ thymidine prior to harvesting for scintillation counting. Data are reported as the stimulation index, which is calculated as the mean counts per minute of cultures stimulated with Rev divided by the mean counts per minute of cultures without Rev stimulation.
TABle 2. APPEARANCE of Rev-Reactive HTLS Following GENETIC IMMUNIZATION ${ }^{\mathrm{a}}$

\begin{tabular}{lcc}
\hline $\begin{array}{l}\text { No. of plasmid } \\
\text { injections }\end{array}$ & $\begin{array}{c}\text { HTL frequency } \\
(95 \% \text { CI })\end{array}$ & $\begin{array}{c}\text { PTL frequency } \\
(95 \% C I)\end{array}$ \\
\hline None & $1 / 189,907$ & $1 / 20,009$ \\
1 & $(1 / 84,383-1 / 757,970)$ & $(1 / 13,304-1 / 40,336)$ \\
& $<1 / 268,750$ & $1 / 17,343$ \\
2 & $1 / 14,446$ & $(1 / 11,949-1 / 31,611)$ \\
& $(1 / 10,168-1 / 24,939)$ & $(1 / 10,466-1 / 24,283)$ \\
3 & $1 / 10,562$ & $1 / 9,014$ \\
& $(1 / 8,073-1 / 15,270)$ & $(1 / 6,182-1 / 16,633)$ \\
4 & $1 / 14,421$ & $1 / 12,685$ \\
& $(1 / 10,198-1 / 24,614)$ & $(1 / 9,183-1 / 20,503)$ \\
4 & $1 / 8,000$ & $1 / 5,493$ \\
$(6$ weeks & $(1 / 5,561-1 / 14,259)$ & $(1 / 4,227-1 / 7,842)$ \\
post $)^{b}$ & $1 / 75,565$ & Not determined \\
$4(\beta-G a l$ & $(1 / 43,186-1 / 301,954)$ & \\
control $)^{c}$ & &
\end{tabular}

${ }^{\mathrm{a} B A L B} / \mathrm{c}$ mice were given varying numbers of biweekly intramuscular injections of $100 \mu \mathrm{g}$ of plasmid encoding Rev M10. Ten days after the indicated number of injections, splenocytes were processed for use as responder cells in Rev-reactive HTL and PTL LDAs.

${ }^{\text {b }}$ Splenocytes were harvested 6 weeks after the fourth Rev M10 plasmid immunization.

${ }^{\mathrm{c}}$ As a plasmid control, mice were given four biweekly immunizations with a plasmid encoding $\beta$-galactosidase.

Abbreviations: HTL, Helper T lymphocyte; PTL, proliferating T lymphocyte.

best reflects the ability to mount a deleterious immune response following cardiac transplantation in both mice (Bishop et al., 1992) and humans (DeBruyne et al., 1993, 1995). Hence, we adapted our previously described limiting dilution analysis (LDA) technique (Bishop and Orosz, 1989) to quantify Rev-reactive IL-2-producing HTLs.

Initial studies evaluated the kinetic appearance of Rev-reactive HTLs in the spleens of BALB/c mice following multiple biweekly injections with pCMV Rev M10. As shown in Table 2, Rev-reactive HTLs were rare or not detectable in the spleens of naive mice $(1 / 189,907)$. However, Rev-reactive HTLs appeared following the second immunization with pCMV Rev M10 and leveled off over the third and fourth plasmid injections. This induction of Rev-reactive HTLs by pCMV Rev M10 immunization has been observed in more than 20 separate experiments, with the frequency of Rev-reactive HTLs ranging from approximately $1 / 1000-1 / 15,000$. In addition, these Revreactive HTLs persisted in the spleens of mice for at least 6 weeks following the fourth genetic immunization (Table 2). As an additional negative control, mice received 4 intramuscular injections with a plasmid encoding $\beta$-galactosidase. Immunization with this $\beta$-galactosidase plasmid failed to induce a significant frequency of Rev-reactive HTLs (Table 2). Finally, it should be noted that the ability to mount a Rev-reactive HTL response is not unique to the $\mathrm{BALB} / \mathrm{c}$ mouse, in that $\mathrm{C} 57 \mathrm{BL} / 6$ mice immunized with pCMV Rev M10 developed similar HTL responses (data not shown).

Table 2 also illustrates the frequency of proliferating $\mathrm{T}$ lymphocytes (PTLs) in LDA microcultures that are supplemented 
Table 3. Presence of Rev-Reactive IL-2-Producing

HTLS IN THE ABSENCE of AdDitional CytokInes ${ }^{a}$

\begin{tabular}{lcccc}
\hline Experiment & $\begin{array}{c}I L-2 \text { HTL frequency } \\
(95 \% \text { CI })\end{array}$ & $\begin{array}{c}I F N-\gamma \\
(\mathrm{ng} / \mathrm{ml})\end{array}$ & $\begin{array}{c}I L-4 \\
(\mathrm{ng} / \mathrm{ml})\end{array}$ & $\begin{array}{c}I L-10 \\
(\mathrm{ng} / \mathrm{ml})\end{array}$ \\
\hline 1 & $\begin{array}{c}1 / 13,792 \\
(1 / 9,620-1 / 24,354) \\
1 / 8,577\end{array}$ & 0.87 & $\mathrm{ND}^{\mathrm{b}}$ & $\mathrm{ND}$ \\
2 & $(1 / 6,466-1 / 12,732)$ \\
3 & $\begin{array}{c}1 / 1,856 \\
(1 / 1,414-1 / 2,697)\end{array}$ & $\mathrm{ND}$ & $\mathrm{ND}$ & $\mathrm{ND}$ \\
ConA & - & 6.1 & $\mathrm{ND}$ & $\mathrm{ND}$ \\
\hline
\end{tabular}

${ }^{\mathrm{a} B A L B} / \mathrm{c}$ mice received three to four biweekly intramuscular injections of a plasmid encoding Rev M10. Ten days after the last immunization, splenocytes were harvested and used as responder cells in an Rev-reactive HTL LDA, or cultured at $1 \times 10^{6}$ cells $/ \mathrm{ml}$ in the presence of $0.1 \mu \mathrm{g}$ of Rev $/ \mathrm{ml}$. Supernatants were harvested at $72 \mathrm{hr}$ and IFN- $\gamma$, IL- 4 , and IL-10 concentrations were BALB/c splenocytes stimulated with $1 \mu \mathrm{g}$ of $\mathrm{ConA} / \mathrm{ml}$ for $72 \mathrm{hr}$.

bND, Not detectable.

with exogenous IL-2. This PTL LDA is designed to quantify the number of cells capable of proliferating in response to a given antigen when exogenous growth factors are provided. In contrast to HTLs, PTLs were detectable in naive mice $(1 / 20,009)$, although they increased in number following pCMV Rev M10 immunization. These data suggest that while precursor cells with the potential to respond to Rev are present in naive animals at appreciable frequencies, the limiting factor in mounting an anti-Rev immune response is the IL-2-producing HTL. Further, these data indicate that monitoring HTL frequencies may be used as a sensitive indicator of an Rev M10induced response.

\section{Failure to detect additional cytokine production by Rev-reactive $T$ cells}

We also assessed the ability of splenocytes obtained from pCMV Rev M10-immunized mice to produce IFN- $\gamma$, IL-4, and IL-10. Briefly, immune splenocytes were cultured at $1 \times$ $10^{6} / \mathrm{ml}$ in the presence or absence of recombinant Rev $(0.1$ $\mu \mathrm{g} / \mathrm{ml}$ ). Culture supernatants were harvested at 24 and $72 \mathrm{hr}$ and assessed for cytokine content by standard enzyme-linked immunosorbent assay (ELISA). The results of three separate experiments are depicted in Table 3. Despite the presence of IL-2-producing HTLs, IL-4 and IL-10 were not detectable by ELISA, and IFN- $\gamma$ concentrations were low or not detectable. In additional experiments, immune splenocytes were cultured with Rev for 5 days, then restimulated with Rev in fresh medium for an additional $72 \mathrm{hr}$. Cytokine production in these secondary cultures was also not detectable (data not shown). Hence, while pCMV Rev M10 immunization induced IL-2-producing HTLs that were readily detectable by LDA, ELISAs failed to detect the production of additional cytokines by immune $T$ cells.

\section{Phenotype of Rev-reactive helper $T$ lymphocytes}

Since IL-2-producing HTLs are $\mathrm{CD} 4^{+} \mathrm{T}$ cells in many (but not all) systems, we depleted $\mathrm{CD}^{+}$or $\mathrm{CD} 8^{+}$cells following the third immunization with pCMV Rev M10 and quantified Rev-reactive HTLs in the selected populations by LDA. As shown in Table 4 , depletion of $\mathrm{CD}^{+}$cells markedly reduced the frequency of Rev-reactive HTLs (1/16,838 $\rightarrow 1 / 52,942)$, indicating that the majority of HTLs were $\mathrm{CD} 4^{+}$. Further, depletion of $\mathrm{CD} 8^{+}$cells increased the frequency of Rev-reactive HTLs (1/5728), likely reflecting the enrichment for CD4 ${ }^{+}$cells following removal of the $\mathrm{CD} 8^{+}$population.

\section{TGF $\beta 1$ gene transfer inhibits Rev-reactive helper $T$ lymphocyte development}

We next asked if the immune response induced by pCMV Rev M10 immunization could be circumvented by cotransfection with plasmids encoding immunosuppressive agents. To this end, BALB/c mice received three immunizations with either pCMV Rev M10 alone, or pCMV Rev M10 plus a plasmid encoding the active form of human TGF $\beta 1$. The frequencies of Rev-reactive IL-2-producing HTLs in the spleens of these mice are shown in Table 5. As described above, immunization with pCMV Rev M10 alone resulted in the development of readily detectable Rev-reactive HTLs (1/11,973). Interestingly, cotransfection with a plasmid encoding the immunosuppressive

Table 4. Phenotype of Rev-Reactive IL-2-PRODUCING HTLs ${ }^{a}$

\begin{tabular}{lc}
\hline In vitro depletion & $\begin{array}{c}\text { HTL frequency } \\
(95 \% \mathrm{CI})\end{array}$ \\
\hline None & $1 / 16,838$ \\
Anti-CD4 & $(1 / 11,825-1 / 29,225)$ \\
Anti-CD8 & $1 / 52,942$ \\
& $(1 / 32,343-1 / 145,784)$ \\
& $1 / 5,728$ \\
& $(1 / 11,873-1 / 26,145)$
\end{tabular}

${ }^{a} B A L B / c$ mice received three biweekly intramuscular injections of $100 \mu \mathrm{g}$ of plasmid encoding Rev M10. Ten days after the third immunization, splenocytes were harvested and depleted of either $\mathrm{CD}^{+}{ }^{+}$or $\mathrm{CD}{ }^{+} \mathrm{T}$ cells, or left untreated. Resulting populations were used as responder cells in an Rev-reactive HTL LDA. 
Table 5. TGF $\beta 1$ Gene Cotransfer Inhibits Rev-REACTIVE HTL DEVELOPMENT ${ }^{a}$

\begin{tabular}{lc}
\hline Plasmid encoding: & $\begin{array}{c}\text { HTL frequency } \\
(95 \% \text { CI })\end{array}$ \\
\hline Rev M10 & $1 / 11,973$ \\
Rev M10 + TGF $\beta 1$ & $(1 / 8,537-1 / 20,037)$ \\
& $1 / 130,389$ \\
& $(1 / 63,292-1 / 2,168,547)$ \\
\hline
\end{tabular}

${ }^{\mathrm{a} B A L B} / \mathrm{c}$ mice received three biweekly intramuscular injections of either $100 \mu \mathrm{g}$ of plasmid encoding Rev M10 or a mixture of $100 \mu \mathrm{g}$ of plasmid encoding Rev M10 plus $100 \mu \mathrm{g}$ of plasmid encoding the active form of human TFG $\beta 1$. Ten days after the third injection, splenocytes were isolated for use as responder cells in an Rev-reactive HTL LDA.

cytokine TGF $\beta 1$ markedly decreased the frequency of Rev-reactive HTLs $(1 / 130,389)$. Hence, while gene transfer strategies may induce an immune response, these responses may be tempered by cotransfer of genes encoding appropriate immunosuppressive agents.
Rev MI0 gene transfer does not induce detectable IgG antibody production

Since a vigorous HTL response was induced following genetic vaccination with Rev M10, we asked whether these HTLs provided help for the production of anti-Rev antibodies. An ELISA was employed to detect Rev-reactive IgG and IgM in the sera of mice that had received three injections with pCMV Rev M10 (Fig. 1). In more than 10 separate experiments, Revreactive IgG antibodies were not detectable by ELISA. While low levels of Rev-reactive IgM antibodies were detectable in the sera of pCMV Rev M10-immunized mice, similar levels of these IgM antibodies were present in the sera of naive mice (Fig. 1). One possible explanation for these negative results was that the recombinant Rev protein used to coat the ELISA plate did not adhere effectively to the plate. To test this possibility, varying concentrations of an anti-Rev $\operatorname{IgG}_{1}$ MAb were used as the primary antibody in the ELISA. As shown in Fig. 1, reactivity with the anti-Rev MAb was readily demonstrable, verifying the utility of this Rev ELISA in detecting anti-Rev antibodies. Finally, to demonstrate that BALB/c mice could mount a detectable anti-Rev IgG response, we immunized animals intraperitoneally with recombinant Rev in Freund's complete ad-

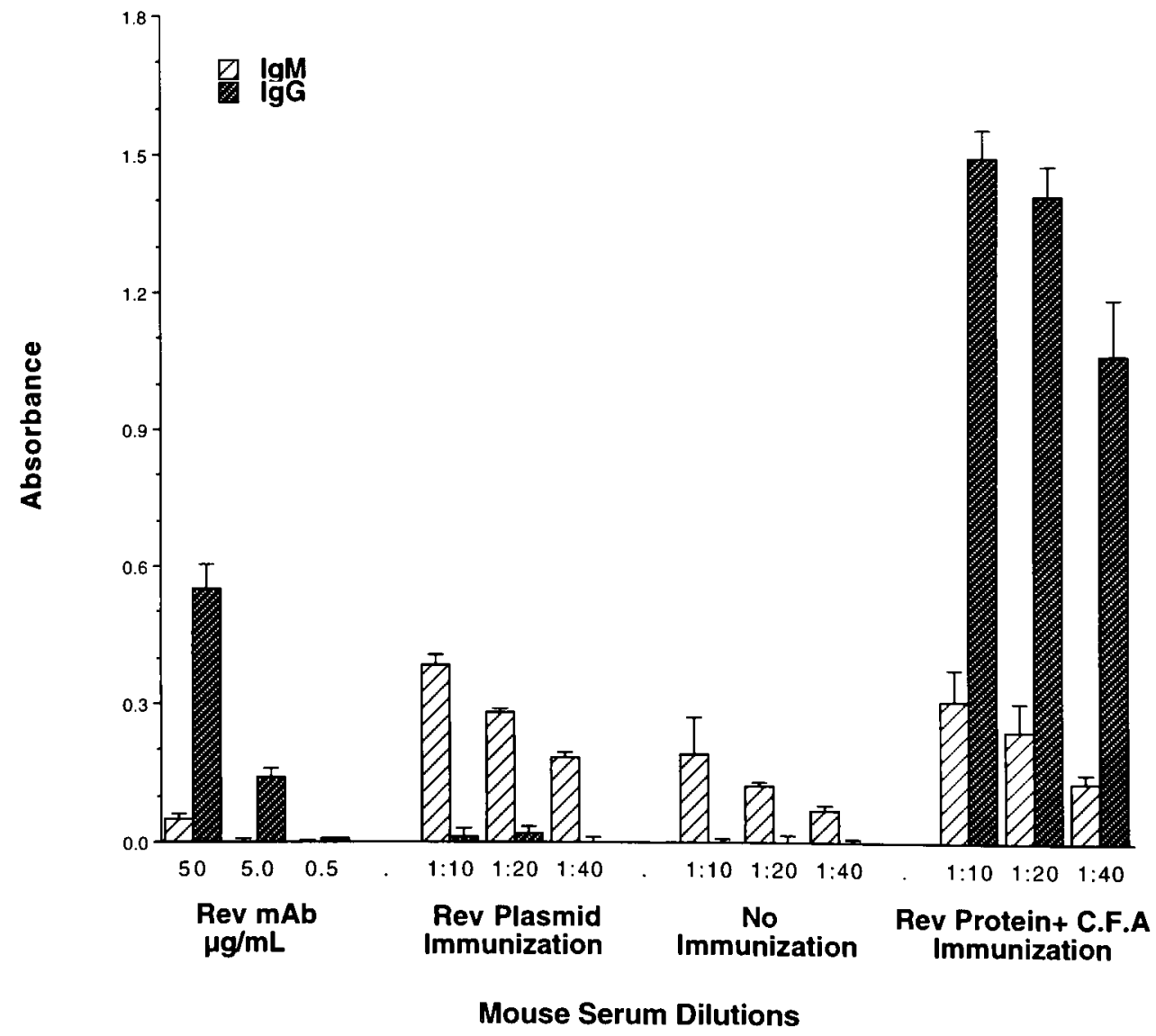

FIG. 1. Rev M10 genetic vaccination does not induce the production of IgG antibodies. An ELISA was used to measure AntiRev antibodies in dilutions of sera obtained from BALB/c mice 10 days after the third intramuscular injection of the Rev M10encoding plasmid pCMV Rev M10 (see Materials and Methods). ELISA detection antibodies were specific for either mouse IgM or IgG. A Rev-specific IgG 1 MAb served as a positive control. Results are compared with those obtained from the sera of naive mice, and with the sera of mice 21 days following intraperitoneal immunization with $100 \mu \mathrm{g}$ of recombinant Rev in Freund's complete adjuvant. 
juvant. As shown in Fig. 1, these mice mounted a strong antiRev IgG response by day 21 postimmunization.

\section{DISCUSSION}

The efficacy of in vivo gene transfer strategies is limited by the relative immunogenicity of both the transgene product and the vector employed to facilitate transfection. Gene transfer-induced immune responses may eliminate transfected cells, thereby limiting duration of transgene expression. Further, local inflammation induced by the transgene product and/or vector within transfected tissues may compromise normal tissue function, thereby exacerbating, rather than alleviating, the original disease process. The current study focused on the immune response induced by in vivo introduction of the anti-HIV gene, Rev M10. Transfection of human T cells with Rev M10 renders these cells resistant to HIV replication in vitro (Bevec et al., 1992; Malim et al., 1992; Woffendin et al., 1994), and cells that have been retrovirally transduced with Rev M10 may persist for extended periods when reintroduced into HIV-infected individuals in vivo (Ranga et al., 1998). Nonetheless, the effects of the immune response on the long-term survival and function of Rev M10-transduced cells have not been established, and may negatively influence the efficacy of this antiHIV gene therapy. Indeed, Riddell et al. (1996) reported that T cells that expressed a foreign selection marker were eliminated by the immune response to the transgene product when these cells were introduced into HIV-infected individuals. To date, the potential immunogenicity of Rev M10 gene transfer has not been rigorously explored. Hence, mice were deliberately immunized by repeated intramuscular administrations of plasmid encoding Rev M10 in an attempt to define immune parameters that could be mobilized by Rev M10 gene transfer.

Studies that have assessed the cellular immune responses to Rev are limited. Blazevic et al. (1995) attempted to identify immunogenic regions of Rev by evaluating the ability of polyclonal $T$ cell lines obtained from HIV-infected individuals to incorporate deoxyuridine when stimulated with synthetic Rev peptides. Several peptides approximately 15 amino acids in length had stimulatory activity for polyclonal $\mathrm{T}$ cell lines obtained from some, but not all, individuals. Weak cytotoxic $\mathrm{T}$ lymphocyte (CTL) responses were also detectable when autologous Epstein-Barr virus (EBV)-transformed B cells were pulsed with these peptides and used as CTL target cells. However, responses were quite variable, and the majority of individuals failed to respond to any of the 13 peptides tested (Blazevic et al., 1995). Similar to our study, Shiver et al. (1995) reported that vaccination of mice with a Rev-encoding plasmid generated cells that proliferated in response to recombinant $\mathrm{Rev}$ protein in vitro. Further, Shiver et al. stated that IFN- $\gamma$, but not IL-4, was produced when splenocytes from plasmid-vaccinated mice were stimulated with Rev in vitro. However, the amount of IFN- $\gamma$ produced by these cells was not presented. In the current study, we assessed Rev-induced production of IFN- $\gamma$, IL4 , and IL- 10 by splenocytes obtained from mice following multiple immunizations with Rev M10-encoding plasmids (Table 3). IL-4 and IL-10 were not detectable by ELISA in the supernatants of these Rev-stimulated splenocytes, and IFN- $\gamma$ production was limited or not detectable. It should be noted that plasmid pCMV Rev M10 used in our study contains a kanamycin resistance gene, while the Rev-encoding plasmid employed by Shiver et al. was derived from pUC19, which contains an ampicillin selection marker. Sato et al. (1996) reported that the unmethylated $\mathrm{CpG}$ motifs present in the ampicillin, but not the kanamycin, resistance gene promote the development of IFN- $\gamma$-producing helper T cell type 1 (Th1) cells following DNA vaccination. Hence, differences in the Rev-induced IFN$\gamma$ response observed in our study and that of Shiver et al. may reflect differences in the $\mathrm{CpG}$ content of the plasmids employed. Alternatively, differences may be attributed in part to the use of plasmids encoding wild-type Rev versus Rev M10. However, it should be noted that Rev M10 differs from wild-type Rev by only two amino acid substitutions (Malim et al., 1991). The impact of this difference on the immune response to Rev has not been defined.

Like Shiver et al. (1995), we found that Rev M10 gene transfer induced a vigorous proliferative response to Rev (Table 1). This response was observed when splenocytes from immunized, but not naive, mice were cultured at high cell concentration $\left(1 \times 10^{6} / \mathrm{ml}\right)$ in the presence of recombinant Rev. Proliferation in these bulk cultures suggested that cells capable of producing IL- 2 or other T cells growth factors were induced by Rev M10 genetic immunization. In addition, PTL LDA revealed that cells with the potential to proliferate to Rev were readily detectable in both immunized and naive mice (Table 2). Since the PTL LDA employed in this study is supplemented with exogenous IL-2, this observation suggested that a limiting factor in the ability of naive cells to respond to Rev was a requirement for Rev-reactive IL-2 producing cells. Indeed, we (Bishop et al., 1992; DeBruyne et al., 1993, 1995) and others (Theobald et al., 1992) have reported that the presence of $\mathrm{IL}$-2-producing HTL reflects the ability of an individual to mount a clinically significant immune response to alloantigens. As predicted, Revreactive HTLs were not present in naive mice, but appeared following two genetic immunizations with pCMV Rev M10 (Table 2).

The observation that Rev-reactive HTLs were $\mathrm{CD}^{+}{ }^{+}$(Table 4) is of interest. Rev is a DNA-binding protein and therefore is not actively secreted. Hence, the Rev M10 transgene product should not be readily available for presentation to $\mathrm{CD} 4^{+}$ cells via the class II antigen presentation pathway (reviewed by Braciale and Braciale, 1991). Given the cellular localization of Rev, one might predict that gene transfer of Rev M10 would preferentially stimulate $\mathrm{CD}^{+} \mathrm{T}$ cells via class I antigen presentation. However, we were unable to detect Rev-reactive CD8 ${ }^{+}$CTLs, using established LDA techniques (Orosz et al., 1989; Bishop et al., 1992; Nabel et al., 1996) with Rev M10-transduced RENCA cells serving as CTL targets (data not shown). Nonetheless, CD4 ${ }^{+}$HTLs were reproducibly induced by pCMV Rev M10 immunization, indicating that the transgene product entered the class II antigen presentation pathway. However, genetic vaccination did not stimulate an anti-Rev antibody response (Fig. 1), indicating that the transgene product was not available for recognition by B cells. Shiver et al. (1995) also reported that genetic immunization with Rev failed to elicit an antibody response. It should be noted that Rev may induce an antibody response in both HIV-infected individuals (Devash et al., 1990) and in mice immunized with Rev protein (Fig. 1 and Voll et al., 1990). Hence, the mode of delivery of Rev ap- 
pears to influence the scope of the response that is elicited. Others have reported that the nature of a transgene-induced response may be influenced by the route of DNA administration and by the tissue and cell types that are transfected. For example, Raz et al. (1994) reported an antibody, rather than a cellular response, was induced when the transgene was introduced intradermally, as opposed to intramuscularly. Similarly, Feltquate et al. (1997) reported that a Thl response is preferentially induced by a transgene product when plasmids are introduced in saline. In contrast, gene gun delivery of the DNA preferentially induces a Th2 response to the transgene product. Aspects of the immune response induced by the introduction of Rev M10-transduced hematopoietic cells in humans have not been defined, and are currently being explored in our laboratory.

Several immunosuppressive strategies have been explored as a means to inhibit the immune response to both transgene products and viral vectors. These include inhibitors of cytokine synthesis such as cyclosporin A (Fang et al., 1995), blockade of costimulatory pathways with either CTLA4Ig (Kay et al., 1995) or anti-CD40 ligand MAb (Yang et al., 1996), and transient depletion of $\mathrm{CD}^{+}{ }^{+} \mathrm{T}$ cells (DeMatteo et al., 1996). In addition, coadministration of genes encoding immunosuppressive agents shows promise as an alternate approach to control gene transfer-induced responses. Examples of this strategy include the transfer of genes encoding immunosuppressive proteins of the E3 region of adenovirus (Lee et al., 1995; Ilan et al., 1997), IL-1 receptor antagonist (McCoy et al., 1995), and the EBV product viral IL-10 (Qin et al., 1997). Our observation that cotransfer of a plasmid encoding the active form of human TGF $\beta 1$ ablates the HTL response induced by Rev M10 genetic vaccination (Table 5) further supports the utility of "genetic immunosuppression" in the management of transgene-induced immune responses. TGF $\beta 1$ is a pleiotrophic cytokine that mediates multiple antiinflammatory activities (Wahl, 1994), including inhibition of 'Th1 responses (Schmitt et al., 1994), E-selectin expression by endothelial cells (Gamble et al., 1993), and CTL development (Inge et al., 1992). However, excess production or systemic administration of TGF $\beta 1$ has been associated with unresolved inflammation and fibrosis (Border and Ruoslahti, 1992; Wahl, 1994). It should be noted that no adverse effects were observed when mice received intramuscular injections of plasmid encoding TGF $\beta 1$ in this study. Parameters assessed included physical activity, weight loss, coat condition, and splenomegaly. Hence, local delivery of TGF $\beta 1$ via plasmid inoculation provided the desired immunosuppressive effect without overt toxicity.

To our knowledge, this study represents the first to quantify IL-2-producing HTLs as an indicator of the immune response induced by a plasmid encoding Rev M10 in vivo. We suggest that similar HTL responses may be mounted to other transgene products, and that LDA may prove useful in monitoring the evolution of gene transfer-induced immune responsiveness in the setting of replacement gene therapy and of genetic vaccination. Finally, data from this study support the feasibility of combining genes that encode immunosuppressive cytokines with the transgene of interest as a modification aimed at inhibiting the development of transgene-neutralizing immune responses.

\section{ACKNOWLEDGMENTS}

We would like to thank Judy Stein for administrative assistance and Dr. James C. Lee of the University of Texas Medical Branch (Galveston, TX) for generously providing recombinant Rev protein for these studies. This work was supported by National Institutes of Health Grant AI36606.

\section{REFERENCES}

BAHNER, I., ZHOU, C., YU, X.-J., HAO, Q.-L., GUATELLI, J.C., and KOHN, D.B. (1993). Comparison of trans-dominant inhibitor mutant human immunodeficiency virus type 1 genes expressed by retroviral vectors in human T lymphocytes. J. Virol. 67, 3199-3207.

BEVEC, D., DOBROVNIK, M., HAUBER, J., and BOHNLEIN, E. (1992). Inhibition of human immunodeficiency virus type 1 replication in human $T$ cells by retroviral-mediated gene transfer of a dominant-negative Rev trans-activator. Proc. Natl. Acad. Sci. U.S.A. 89, 9870-9874.

BISHOP, D.K., and OROSZ, C.G. (1989). Limiting dilution analysis for allo-reactive, TCGF-secreting T cells: LDA methods that discriminate between unstimulated precursor $T$ cells and in vivo alloactivated $T$ cells. Transplantation 47, 671-677.

BISHOP, D.K., FERGUSON, R.M., and OROSZ, C.G. (1992). Differential distribution of antigen specific helper $T$ cells and cytotoxic $\mathrm{T}$ cells following antigenic stimulation in vivo: A functional study using limiting dilution analysis. J. Immunol. 144, 1153-1160.

BLAESE, R.M., CULVER, K.W., MILLER, A.D., CARTER, C.S., FLEISHER, T., CLERICI, M., SHEARER, G., CHANG, L., CHIANG, Y., TOLSTOSHEV, P., GREENBLATT, J.J., ROSENBERG, S.A., KLEIN, H., BERGER, M., MULLEN, C.A., RAMSEY, W.J., MUUL, L., MORGAN, R.A., and ANDERSON, W.F. (1995). T lymphocyte-directed gene therapy for ADA- SCID: Initial trial results after 4 years. Science 270, 475-480.

BLAZEVIC, V., RANKI, A., and KROHN, K.J.E. (1995). Helper and cytotoxic T cell responses of HIV type 1-infected individuals to synthetic peptides of HIV type 1 Rev. AIDS Res. Hum. Retroviruses 11, 1335-1342.

BORDER, W.A., and RUOSLAHTI, E. (1992). Transforming growth factor $-\beta$ in disease: The dark side of tissue repair. J. Clin. Invest. 90, 1 .

BRACIALE, T.J., and BRACIALE, V.L. (1991). Antigen presentation: Structural themes and functional variations. Immunol. Today 12, 124-129.

CULLEN, B.R., HAUBER, J., CAMPBELL, K., SODROSKI, J.G., HASELTINE, W.A., and ROSEN, C.A. (1988). Subcellular localization of the human immunodeficiency virus trans-acting art gene product. J. Virol. 62, 2498-2501.

DAVIS, H.L., SCHIRMBECK, R., REIMANN, J., and WHALEN, R.G. (1995). DNA-mediated immunization in mice induces a potent MHC class I-restricted cytotoxic T lymphocyte responses to the hepatitis B envelope protein. Hum. Gene Ther. 6, 1447-1456.

DEBRUYNE, L.A., ENSLEY, R.D., OLSEN, S.L., TAYLOR, D.O., CARPENTER, B.M., HOLLAND, C., SWANSON, S., JONES, K.W., KARWANDE, S.V., RENLUND, D.G., and BISHOP, D.K. (1993). Increased frequency of alloantigen-reactive helper T lymphocytes is associated with human cardiac allograft rejection. Transplantation 56, 722-727.

DEBRUYNE, L.A., RENLUND, D.G., and BISHOP, D.K. (1995). Evidence that human cardiac allograft acceptance is associated with a decrease in donor-reactive helper $T$ lymphocytes. Transplantation 59 ,
$778-783$. 
DEMATTEO, R.P., MARKMANN, J.F., KOZARSKY, K.F. BARKER, C.F., and RAPER, S.E. (1996). Prolongation of adenoviral transgene expression in mouse liver by $\mathrm{T}$ lymphocyte subset depletion. Gene Ther. 3, 4-12.

DEVASH, Y., REAGAN, K., WOOD, D., TURNER, J., PARRINGTON, M., and KANG, C.Y. (1990). Antibodies against AIDS proteins. Nature (London) 345, 581.

DWARKI, V.J., BELLONI, P., NIJJAR, T., SMITH, J., COUTO, L., RABIER, M., CLIFT, S., BERNS, A., and COHEN, L.K. (1995). Gene therapy for hemophilia A: Production of therapeutic levels of human factor VIII in vivo in mice. Proc. Natl. Acad. Sci. U.S.A. 92, 1023-1027.

FANG, B., EISENSMITH, R.C., WANG, H., KAY, M.A., CROSS, R.E., LANDEN, C.N., GORDON, G., BELLINGER, D.A., READ, M.S., HU, P.C., BRINKHOUS, K.M., and WOO, S.L.C. (1995). Gene therapy for hemophilia B: Host immunosuppression prolongs the therapeutic effect of adenovirus-mediated factor IX expression. Hum. Gene Ther. 6, 1039-1044.

FELTQUATE, D.M., HEANEY, S., WEBSTER, R.G., and ROBINSON, H.L. (1997). Different T helper cell types and antibody isotypes generated by saline and gene gun DNA immunization. J. Immunol. 158, 2278-2284.

GAMBLE, J.R., KHEW-GOODALL, Y., and VADAS, M.A. (1993). Transforming growth factor- $\beta$ inhibits E-selectin expression on human endothelial cells. J. Immunol. 150, 4494-4503.

HURWITZ, D.R., KIRCHGESSER, M., MERRILL, W. GALANOPOULOS, T., MCGRATH, C.A., EMAMI, S., HANSEN, M., CHERINGTON, V., APPEL, J.M., BIZINKAUSKAS, C.B., BRACKMANN, H.H., LEVINE, P.H., and GREENBERGER, J.S. (1997). Systemic delivery of human growth hormone or human factor IX in dogs by reintroduced genetically modified autologous bone marrow stromal cells. Hum. Gene Ther. 8, 137-156.

HUYGEN, K., CONTENT, J., DENIS, O., MONTGOMERY, D.L., YAWMAN, A.M., DECK, R.R., DEWITT, C.M., ORME, I.M. BALDWIN, S., D'SOUZA, C., DROWART, A., LOZES, E., VANDENBUSSCHE, P., VAN VOOREN, J.-P., LIU, M.A., and ULMER, J.B. (1996). Immunogenicity and protective efficacy of a tuberculosis DNA vaccine. Nature Med. 2, 893-898.

ILAN, Y., DROGUETT, G., CHOWDHURY, N.R., LI, Y., SENGUPTA, K., THUMMALA, N.R., DAVIDSON, A., CHOWDHURY, J.R., and HORWITZ, M.S. (1997). Insertion of the adenoviral E3 region into a recombinant viral vector prevents antivira humoral and cellular immune responses and permits long-term gene expression. Proc. Natl. Acad. Sci. U.S.A. 94, 2587-2592.

INGE, T.H., HOOVER, S.K., SUSSKIND, B.M., BARRETT, S.K., and BEAR, H.D. (1992). Inhibition of tumor-specific cytotoxic T-lymphocyte responses by transforming growth factor $\beta 1$. Cancer Res. 52, 1386-1392.

KAY, M.A., LANDEN, C.N., ROTHENBERG, S.R., TAYLOR, L.A. LELAND, F., WIEHLE, S., FANG, B., BELLINGER, D., FINEGOLD, M., THOMPSON, A.R., READ, M., BRINKHOUS, K.M., and WOO, S.L.C. (1994). In vivo hepatic gene therapy: Complete albeit transient correction of factor IX deficiency in hemophilia B dogs. Proc. Natl. Acad. Sci. U.S.A. 91, 2353-2357.

KAY, M.A., HOLTERMAN, A.-X., MEUSE, L., GOWN, A., OCHS, H.D., LINSLEY, P.S., and WILSON, C.B. (1995) Long-term hepatic adenovirus-mediated gene expression in mice following CTLA4Ig administration. Nature Genet. 11, 191-197.

KOZARSKY, K.F., BONEN, D.K., GIANNONI, F., FUNAHASHI, T., WILSON, J.M., and DAVIDSON, N.O. (1996). Hepatic expression of the catalytic subunit of the apolipoprotein B mRNA editing enzyme (apobec-1) ameliorates hypercholesterolemia in LDL receptordeficient rabbits. Hum. Gene Ther. 7, 943-957.

LEE, M.G., ABINA, M.A., HADDADA, H., and PERRICAUDET, M. (1995). The constitutive expression of the immunomodulatory gp 19k protein in E1-, E3 - adenoviral vectors strongly reduces the host cytotoxic $T$ cell response against the vector. Gene Ther. 2, 256-262.

LIU, J., WOFFENDIN, C., YANG, Z.-Y., and NABEL, G.J. (1994). Regulated expression of a dominant negative form of Rev improves resistance to HIV replication in T cells. Gene Ther. 1, 32-37.

MALIM, M.H., BOHNLEIN, S., HAUBER, J., and CULLEN, B.R. (1989). Functional dissection of the HIV-1 Rev trans-activator-derivation of a trans-dominant repressor of Rev function. Cell 58, 205-214

MALIM, M.H., MCCARN, D.F., TLEY, L.S., and CULLEN, B.R. (1991). Mutational definition of the human immunodeficiency virus type 1 Rev activation domain. J. Virol. 65, 4248-4254.

MALIM, M.H., FREIMUTH, W.W., LIU, J., BOYLE, T.J., LYERLY, H.K., CULLEN, B.R., and NABEL, G.J. (1992). Stable expression of transdominant Rev protein in human $T$ cells inhibits human immunodeficiency virus replication. J. Exp. Med. 176, 1197-1201.

MCCOY, R.D., DAVIDSON, B.L., ROESSLER, J., HUFFNAGLE, B.B., and SIMON, R.H. (1995). Expression of human interleukin-1 receptor antagonist in mouse lungs using a recombinant adenovirus: Effects on vector-induced inflammation. Gene Ther. 2, 437-442.

MICHEL, M.-L., DAVIS, H.L., SCHLEEF, M., MANCINI, M., TIOLLAIS, P., and WHALEN, R.G. (1995). DNA-mediated immunization to the hepatitis B surface antigen in mice: Aspects of the humoral response mimic hepatitis B viral infection in humans. Proc. Natl. Acad. Sci. U.S.A. 92, 5307-5311.

MOR, G., KLINMAN, D.M., SHAPIRO, S., HAGIWARA, E., SEDEGAH, M., NORMAN, J.A., HOFFMAN, S.L., and STEINBERG, A.D. (1995). Complexity of the cytokine and antibody response elicited by immunizing mice with Plasmodium yoelii circumsporozoite protein plasmid DNA. J. Immunol. 155, 2039-2046.

NABEL, G.J., GORDON, D., BISHOP, D.K., NICKOLOFF, B.J., YANG, Z.-Y., ARUGA, A., CAMERON, M.J., NABEL, E.G., and CHANG, A.E. (1996). Immune response in human melanoma after transfer of an allogeneic class I major histocompatibility complex gene with DNA-liposome complexes. Proc. Natl. Acad. Sci. U.S.A. 93, 15388-15393.

QIN, L., DING, Y., PAHUD, D.R., ROBSON, N.D., SHAKED, A., and BROMBERG, J.S. (1997). Adenovirus-mediated gene transfer of viral IL-10 inhibits the immune response to both alloantigen and adenoviral antigen. Hum. Gene Ther. 8, 1365-1374.

RANGA, U., WOFFENDIN, C., VERMA, S., XU, L., JUNE, C.H., BISHOP, D.K., and NABEL, G.J. (1998). Enhanced T cell engraftment after retroviral delivery of an antiviral gene in HIV-infected individuals. Proc. Natl, Acad. Sci. U.S.A. 95, 1201-1206.

RAZ, E., CARSON, D.A., PARKER, S.E., PARR, T.B., ABAI, A.M., AICHINGER, G., GROMKOWSKI, S.H., SINGH, M., LEW, D., YANKAUCKAS, M.A., BAIRD, S.M., and RHODES, G.H. (1994). Intradermal gene immunization: The possible role of DNA uptake in the induction of cellular immunity to viruses. Proc. Natl. Acad. Sci. U.S.A. 93, $5141-5145$.

RIDDELL, S.R., ELLIOT, M., LEWINSOHN, D.A., GILBERT, M.J., WILSON, L., MANLEY, S.A., LUPTON, S.D., OVERELL, R.W., REYNOLDS, T.C., COREY, L., and GREENBERG, P.D. (1996). T-cell mediated rejection of gene-modified HIV-specific cytotoxic T lymphocytes in HIV-infected patients. Nature Med. 2, 216-223.

ROBINSON, H.L., HUNT, L.A., and WEBSTER, R.G. (1993). Protection against a lethal influenza virus challenge by immunization with a hemagglutinin-expressing plasmid DNA. Vaccine 11, 957-960.

SATO, Y., ROMAN, M., TIGHE, H., LEE, D., CORR, M., NGUYEN, M.-D., SILVERMAN, G.J., LOTZ, M. CARSON, D.A., and RAZ, E. (1996). Immunostimulatory DNA sequences necessary for effective intradermal gene immunization. Science 273, 352-354

SCHIRMBECK, R., BOHM, W., and REIMANN, J. (1996). DNA vaccination primes MHC class I-restricted, simian virus 40 large tumor 
antigen-specific CTL in $\mathrm{H}-2 \mathrm{~d}$ mice that reject syngeneic tumors. J. Immunol. 157, 3550-3558.

SCHMITT, E., HOEHN, P., HUELS, C., GOEDERT, S., PALM, N., RUDE, E., and GERMANN, T. (1994). T helper type 1 development of naive $\mathrm{CD} 4+\mathrm{T}$ cells requires the coordinate action of interleukin12 and interferon- $\gamma$ and is inhibited by transforming growth factor$\beta$. Eur. J. Immunol. 24, 793-798.

SHIVER, J.W., PERRY, H.C., DAVIES, M.-E., FREED, D.C., and LIU, M.A. (1995). Cytotoxic T lymphocyte and helper T cell responses following HIV polynucleotide vaccination. Ann. N.Y. Acad. Sci. 772, 198-208.

SODROSKI, J., GOH, W.C., ROSEN, C., DAYTON, A., TERWILLIGER, E., and HASELTINE, W. (1986). A second post-transcriptional trans-activator gene required for HTLV-III replication. Nature (London) 321, 412-417.

TANG, D.-C., DEVIT, M., and JOHNSTON, S.A. (1992). Genetic immunization is a simple method for eliciting an immune response. Nature (London) 356, 152-154.

TASWELL, C. (1981). Limiting dilution assays for the determination of immunocompetent cell frequencies. I. Data analysis. J. Immunol. 126, 1614-1619.

THEOBALD, M., NIERLE, T., BUNJES, D., ARNOLD, R., and HEIMPLE, H. (1992). Host-specific interleukin-2-secreting donor Tcell precursors as predictors of acute graft-versus-host disease in bone marrow transplantation between HLA-identical siblings. N. Engl. J. Med. 327, 1613-1617.

TRIPATHY, S.K., BLACK, H.B., GOLDWASSER, E., and LEIDEN, J.M. (1996). Immune responses to transgene-encoded proteins limit the stability of gene expression after injection of replication-defective adenovirus vectors. Nature Med. 2, 545-550.

VOLL, R., AEPINUS, C., KRAPF, F., HERRMANN, M., KALDEN,
J.R., and FLECKENSTEIN, B. (1990). Monoclonal antibodies directed against the Rev protein of human immunodeficiency virus type 1. Mol. Cell. Prob. 4, 63-72.

WAHL, S.M. (1994). Transforming growth factor $\beta$ : The good, the bad, and the ugly. J. Exp. Med. 180, 1587-1590.

WOFFENDIN, C., YANG, Z.-Y., RANGA, U., XU, L., YANG, N.-S., SHEEHY, M.J., and NABEL, G.J. (1994). Nonviral and viral delivery of a human immunodeficiency virus protective gene into primary human T cells. Proc. Natl. Acad. Sci. U.S.A. 91, 11581-1 1585.

YANG, Y., SU, Q., GREWAL, I.S., SCHILZ, R., FLAVELL, R.A., and WILSON, J.M. (1996). Transient subversion of CD40 ligand function diminishes immune responses to adenovirus vectors in mouse liver and lung tissues. J. Virol. 70, 6370-6377.

YANKAUCKAS, M.A., MORROW, J.E., PARKER, S.E., ABAI, A., RHODES, G.H., DWARKI, V.J., and GROMKOWSKI, S.H. (1993). Long-term anti-nucleoprotein cellular and humoral immunity is induced by intramuscular injection of plasmid DNA containing NP gene. DNA Cell Biol. 12, 771-776.

\section{Address reprint requests to: \\ Dr. D. Keith Bishop \\ Transplant Immunology Research \\ Section of General Surgery \\ 1150 W. Medical Center Drive \\ A560 MSRB II, Box 0654 \\ University of Michigan Medical Center \\ Ann Arbor, MI 48109}

Received for publication March 11, 1998; accepted after revision July 17, 1998. 